\title{
Applications of Multi-Objective Optimization to Industrial Processes: A Literature Review
}

\author{
Sandra C. Cerda-Flores, Arturo A. Rojas-Punzo and Fabricio Nápoles-Rivera *
}

Department of Chemical Engineering, Universidad Michoacana de San Nicolás de Hidalgo, Santiago Tapia 403, Centro, Morelia 58000, Mexico; 0860289k@umich.mx (S.C.C.-F.); 1142020x@umich.mx (A.A.R.-P.)

* Correspondence: fnapoles@umich.mx; Tel.: +52-4433223500

check for

updates

Citation: Cerda-Flores, S.C.;

Rojas-Punzo, A.A.; Nápoles-Rivera, F. Applications of Multi-Objective Optimization to Industrial Processes: A Literature Review. Processes 2022, 10, 133. https://doi.org/10.3390/ pr10010133

Academic Editor: Jean-Pierre Corriou

Received: 7 December 2021

Accepted: 5 January 2022

Published: 10 January 2022

Publisher's Note: MDPI stays neutral with regard to jurisdictional claims in published maps and institutional affiliations.

Copyright: (c) 2022 by the authors. Licensee MDPI, Basel, Switzerland. This article is an open access article distributed under the terms and conditions of the Creative Commons Attribution (CC BY) license (https:// creativecommons.org/licenses/by/ $4.0 /)$.

\begin{abstract}
Industrial processes provide several of the products and services required for society. However, each industry faces different challenges from different perspectives, all of which must be reconciled to obtain profitable, productive, controllable, safe and sustainable processes. In this context, multi-objective optimization has become a powerful tool to aid the decision-making mechanism in the synthesis, design, operation and control of such processes. The solution to the mathematical models provides the necessary tools to asses the system performance in terms of different metrics and evaluate the trade-offs between the objectives in conflict. The number of applications of multiobjective optimization in industrial processes is ample and each application has its own challenges. In the present literature review, a broad panorama of the applications in multi-objective optimization is presented, including future perspectives and open questions that still need to be addressed.
\end{abstract}

Keywords: multi-objective optimization; industrial processes; optimization

\section{Introduction}

Industrial activity provides most of the products and services required for the population's well-being, for example, food, clothing, energy, water, drugs, vehicles and computers, all of which are obtained in processing facilities. Since the products and services that can be manufactured in industrial facilities are so diverse, the challenges that every industry faces are enormous and specific. From the design, construction, operation and process control, the involved stakeholders are always concerned about how to perform these tasks in an optimal manner. Then, the question is, optimal from what perspective? Usually, investors seek to optimize the process profit and the process engineer might be interested in increasing yield and controllability; for the workers, increasing safety (reducing the risk) is of paramount interest, while, for governments, increasing the number of jobs or reducing the environmental impact are primal objectives. As it can be seen, the objectives can be diverse and, sometimes, these objectives are in conflict with each other. This means that the best solution for a given objective could be the worst for another. Consequently, multi-objective optimization becomes crucial as a problem-solving tool in industrial processes.

Multi-objective optimization (MOO) refers to the application of mathematical programming techniques to the solution of optimization problems in which more than one performance index (objective function) must be improved (maximized or minimized). $\mathrm{MO}$ problems can be classified as MO-LP if all the objective and constraints are linear, MONLP if the model includes at least one nonlinear equation in the objectives or constraints, MO-MIP if the model consists of linear equations and integer and continuous variables and MO-MINLP if the model includes nonlinear equations and integer and continuous variables. The solution to multiple objectives is difficult; instead, the concept of Pareto dominance is usually adopted [1]. This way, instead of obtaining a single solution, a set of Pareto optimal solutions are obtained. To obtain these solutions, two main approaches can be used; the first one consists in classical methods, such as scalarization-based methods, for example, weighted sum [2] or goal programming [3]. The second type of methods uses 
metaheuristics techniques [1]. In recent years, the application of MOO has attracted a lot of attention from the scientific community, with a growing number of publications in the field (Figure 1).

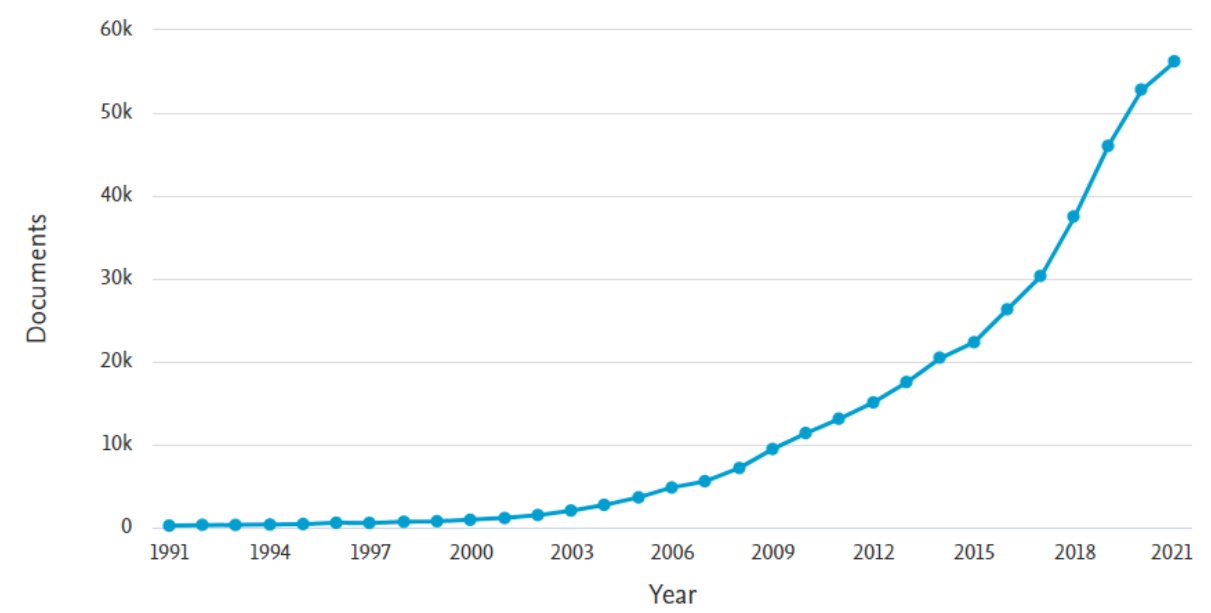

Figure 1. Number of publications related to MOO, 1990-2021 (source: SCOPUS@).

It is particularly interesting how the number of publications related to the fields of engineering, material science, environmental sciences and energy together account for $42.1 \%$ (Figure 2) of the total publications; all these categories are somehow related to the production of goods and services that, as mentioned above, are produced in industrial facilities.

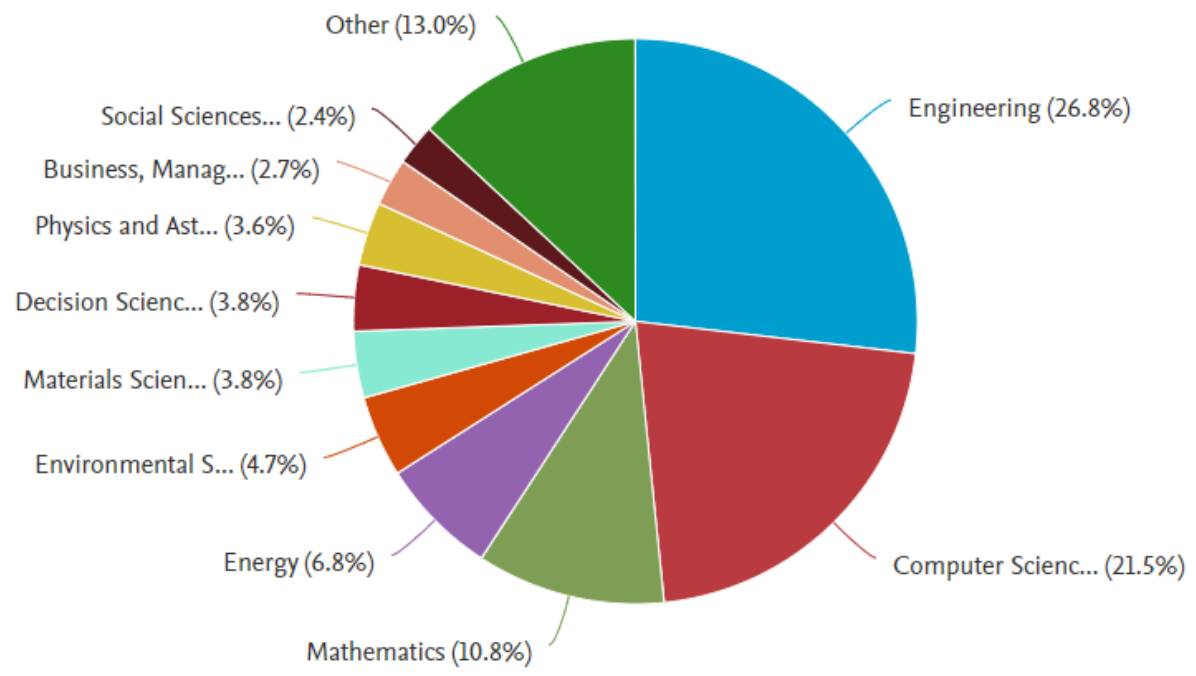

Figure 2. Documents per subject area (source: SCOPUSC).

From MOO models, classification and the increasing amount of publications, it can be inferred that the number of problems that can be formulated as MOO models in the context of industrial processes is very high. Some of the most studied in the recent years are life-cycle assessment, water networks, energy production, storage and distribution, process intensification, supply chains, industrial security evaluation and product development. Taking the above into consideration, it is convenient to compare and analyze various research works to better understand the broad panorama of possibilities provided by the application of multi-objective optimization to industrial processes. 


\section{Application of MOO for Life-Cycle Assessment}

Life-cycle assessment is a technique used to assess the environmental impacts associated with all stages of a product's life, from the extraction of raw material to its processing, manufacturing, distribution and use [4]. Through the combination of life-cycle assessment with $\mathrm{MOO}$, it is possible not only to evaluate the environmental impact for a given process or product, but also to assess the economic perspective, which allows different alternatives for decision-making to be compared [5-8]. An example of the above can be found in studies on circular economy (Figure 3), which aims to convert the value chain from linear to circling and increase the efficiency of resource utilization [9]. In this work, the authors studied the reuse of an organic waste (fish oil), which is usually discarded due to the lack of process recovery, and integrated to the LCA with the economic evaluation. The authors found that the solutions with the highest profit (USD 470,084 per year) also represented an increment of $19.5 \%$ in the LCA score with respect to the configuration with the lowest impact, as well as reducing the shared revenue (social indicator) with respect to the best scenario. This result is typical of $\mathrm{MOO}$ problems in which the defined objectives are in conflict. However, the Pareto fronts give the decision maker a tool to define the priorities and select the best scenario.

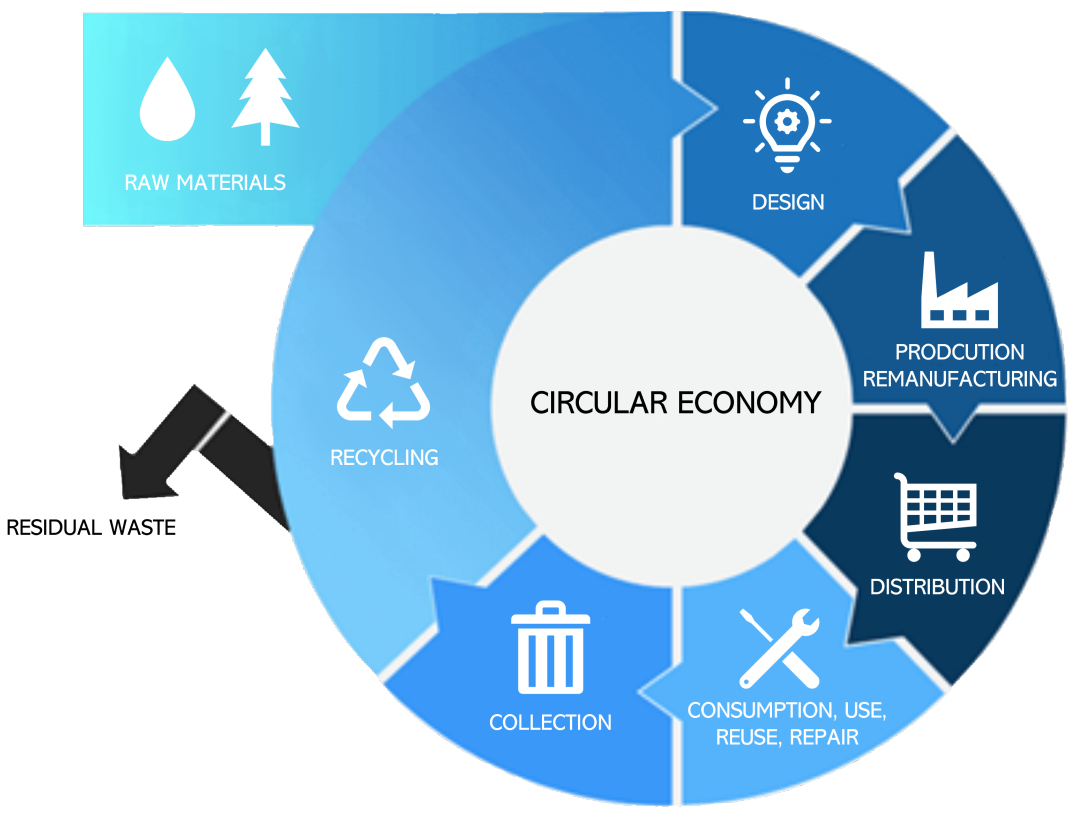

Figure 3. Diagram of circular economy.

There are other works that aim to improve the environmental aspect by designing optimal solid waste management (SWM) systems [10-13]. For example, PourrezaMovahed et al. [10] optimized an SWM system and compared it to recent technologies with enhanced systems that include gas recovery, finding that upgraded technologies provided better results in the economic and environmental aspect with respect to the current practice; however, they considered that the cost function reduced the environmental indicators by $18.2 \%$ ( $\mathrm{CO}_{2}$ equivalent emissions savings) and $6.2 \%$ (Energy consumption savings). Another work also studied the improvement of an SWM [12], finding that the current recovery ratio of organic waste could be increased, in Montreal, from $23 \%$ up to a $100 \%$. These sort of systems are in the spotlight due to the increasing amount of residues generated in major cities around the world; therefore, their proper design and operation can contribute to the development of circular economies.

On the other hand, LCA has also been used to improve the operation strategies of existing processes such as wastewater treatment plants [14]. To address the environmental impact as well as improve energy efficiency in industrial processes, the extensive investiga- 
tion of integrated heat and energy processes is noteworthy. Regarding low-temperature waste heat recovery for power generation, the organic Rankine cycle and the Kalina Cycle are thought of as the most promising and popular technologies in real-world applications [15-18].

It is also possible to find life-cycle assessment research on the manufacture of service products such as concrete, being the second most consumed commodity and the preferred construction material worldwide. As a result, it can be observed that the computational approach allows specific mixtures to be predicted and optimized considering economic and environmental objectives for lightweight concrete production, finding that the performance of the material increases with the cost and also the environmental impact [19].

One of the main challenges when analyzing MO problems in which LCA is considered, consists in defining which is the best metric for the LCA. Some authors include detailed metrics including several impact categories [20], while other authors only analyze one impact, such as total process emissions [21]. Another important challenge resides in the fact that some authors first optimize the process and then perform the LCA to obtain the best alternative in terms of the other objectives. This might lead to sub-optimal solutions in the environmental aspect; therefore, defining appropriate metrics and embedding the LCA in the optimization procedure are the current trends in this area. Finally, the fact that usually the cost objectives are in conflict with the environmental performance leads us to think that the design of new processes can revert this tendency.

\section{Application of MOO to Product Development}

Product development refers to all stages involved between product conceptualization and its release into the market (Figure 4) and it usually involves a discussion on cost reduction, quality improvement and revenue. Some studies have focused on the multiobjective optimization of a product line design [22] to minimize production time and cost of product development, resulting in different options so that the team in charge of said product can evaluate the trade-offs between all the objectives and decide which solution is best for the company. In this work, the authors stress out the important role of experts in the final decision.

Another challenge for product development is to define the operating conditions of the process. Generally, this is performed using a design of experiments; however, it does not guarantee that the best operating conditions are obtained. In this context, MOO can be used to determine the best operating conditions considering different aspects, such as energy, technical, economic and environmental indicators. An example of the above is the MOO research work to find the best operating conditions for the synthesis of methylethyl-ketone oxime [23]. In this work, with the use of $\mathrm{MOO}$, the process was optimized and a compromise solution was selected in such a way that the total cost was increased only by $5.8 \%$ and the energy loss was reduced by $1.54 \%$. Sahoni et al. [24] presented the optimization of the operating conditions for preparing toluene; in this work, the main result indicated that reducing the temperature and pressure yielded significant benefits, increasing the profit from USD 0.0488 per $\mathrm{kg}$ to USD 0.0708 per $\mathrm{kg}$, whilst reducing the environmental burden. Other works aiming to the optimization of the process conditions can be seen in $[25,26]$. These works focus on a single product; however, other works consider an entire product portfolio, such as the dairy or plastic product industry, taking into account a more robust optimization $[27,28]$.

The design of biorefineries is a topic that has been largely studied in this field; in these problems, sometimes, the process structure was optimized to obtain a product from a given feedstock $[29,30]$ and, in other cases, the required feedstock, process structure and portfolio of products were decided [31,32]. Furthermore, authors have studied the supply chain design for new products being developed [33] and how to define the product specifications in the product development phase [34].

For process development, the main problem is finding the properties of a new product that can meet customers' demands and reconcile these characteristics with different steps 
of the production process (i.e., designing processes that meet those characteristics while also considering other objectives). Moreover, the uncertainties in product development and final implementation are still challenges that must be addressed.

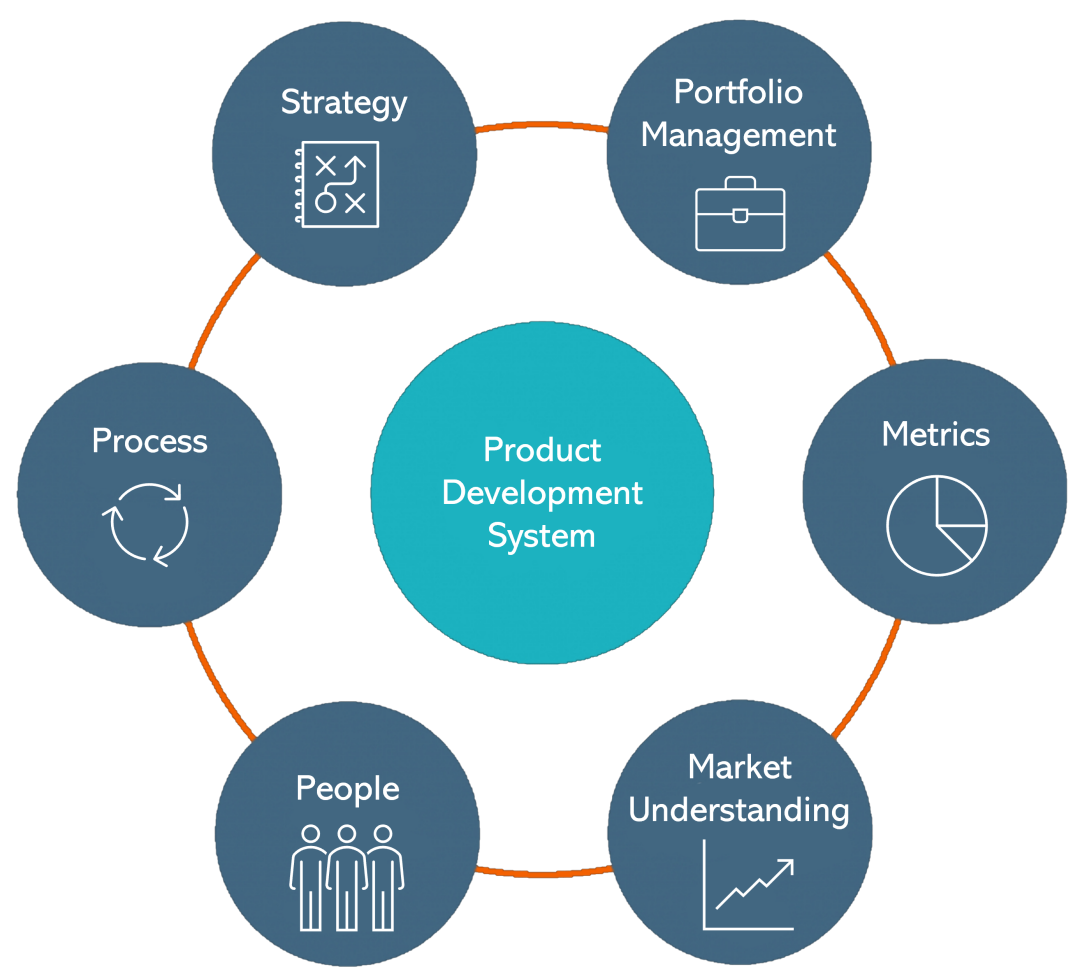

Figure 4. Stages of product development.

\section{Application of MOO in Water Networks}

It is known that one of the critical humanity challenges for the 21st century is dealing with the water crisis. It is estimated that, by 2025, two thirds of the global population will be living under water stress conditions. Due to the ever-rising population growth, industrialization has also become an important contributor to the rapid depletion of natural resources. Therefore, the need to optimize water networks to reduce contaminants in the environment, as well as overall minimization of freshwater use, has risen. A water network includes all of the elements needed, from its extraction, to its storage and distribution. In this context, a general representation of a water network includes water sources, treatment facilities and water sinks; the interactions among all these components can occur at different scales, from industrial processes to macroscopic systems. There are many analyses that discuss not only the integration of wastewater treatment units as a way to reduce freshwater consumption in industries, thus reducing total networks costs and environmental impact [35-40], but also the design of the water treatment plant itself, combining a multi-objective analysis with treatment techniques to obtain the best trade-off solution. Regarding water distribution systems, the challenges arise as a result of the nonlinear relation between various design variables within the piping systems. Therefore, many studies explore the use of different algorithms to solve the multi-objective problem [41-44], resulting in distribution networks that reduce water waste and operation costs, as well as monitoring water quality [45]. A study also focused on the integration of two methodologies to evaluate the criteria (total annualized cost, annual carbon footprint and system reliability) and optimize and develop a ranking of the alternatives in multi-objective problems, using a washing system in a manufacturing process as the case study [46], In this case, it is worth noting that the optimal configuration could reduce the annual costs, in respect to current practice, by $74 \%$ and the carbon footprint by $96 \%$. There is also a research study on the use of intermittent water distribution networks, in which the authors used 
multi-objective optimization tools to maximize the quantitative and qualitative reliability and fairness in water supply, whilst minimizing the frequency of supply interruption [47]. On a similar note, optimization tools have been used to aid in the decision-making process for maintenance and replacement management plans of water distribution networks [48]. An additional relevant application for multi-objective optimization tools is to evaluate the trade-offs between sustainability and economical objectives in the recourse allocation of water resources in order to have a fairer distribution [49,50]. It has also been proven to be efficient to evaluate criteria in order to select a suitable technology for a specific scenario or context in the design of water treatment plants [37,51]. Another topic vastly researched within the use of multi-objective optimization for water networks is the use of water and heat exchange networks in process industries, since the trade-off solutions result in overall cost reductions and less fresh water consumption [52-55]. Several papers have discussed the use of eco-industrial parks to reduce the use of natural resources [56-60]; in such cases, the main objective is to be able to prove that each individual process can operate successfully, while minimizing water/energy use, thus operation costs. Another example of this can be seen in the study that optimized resource integration networks for different sustainability objectives to develop sustainable cluster designs to obtain the maximum economic return, minimum $\mathrm{CO}_{2}$ and water footprint [61].

Although the number of works in this area is abundant, there are limited works dealing with the problem of component material balances. In most cases, overall material balances are used, or simplified schemes in which the mixing of streams is avoided. This practice is common to evade bilinear terms which result in difficult optimization problems. However, this leaves a gap in the field of water networks, as the solutions are sometimes oversimplified, making the final design of water networks difficult, which might include treatment facilities. For the specific case of $\mathrm{WN}$, it is possible to see that a proper design can result in cost minimization but also fresh water consumption reduction. This is because, when using only mixing, the objectives of splitting and re-routing of streams within an industry or group of industries can be simultaneously maximized; however, it is not possible to generalize this behavior when treatment facilities are involved and additional environmental or social objectives are considered.

\section{Application of MOO to Energy Production, Storage and Distribution Systems}

Similarly, the use of fossil fuels has increased exponentially due to population growth and, even though, there are now many clean-energy alternatives, most processes still operate with the use of natural gas and coal as its main energy sources. This brings to the table certain issues that the industry has to consider, such as reduction of greenhouse emissions, as well as the introduction of more sustainable fuels into the system. Many authors have turned to $\mathrm{MOO}$ to aid in solving the problems related to the energy industries. Whether it is used to find the best technologies to mitigate environmental issues [62-64], to assess the possible combination of traditional fuels with other more sustainable options, or finding the best possible energy distribution network, thus lowering costs and optimizing efficiency $[65,66], \mathrm{MOO}$ has become a necessity for the optimal production, storage and distribution of energy systems. A recent publication proposed a consumption-based MOO model through an input-output methodology to pin-point the different sectors in the case study in order to adjust the industrial structure in order to minimize the used energy while maintaining economic growth [67]. Another interesting angle in energy optimization is the multi-objective optimization through energy saving in machining parameters, where the proposed model considers cost and energy consumption [68,69]. Other studies have examined the multi-objective optimization of energy storage, since they are essential to obtain an efficient energy system that could transform from a fossil fuel-dependent system into a more sustainable one [70-72] by comparing different energy storage methods, to evaluate trade-offs regarding cost, technical suitability and environmental impact. One study proposed an MOO framework to analyze the compromise between reducing greenhouse gas emissions and energy storage cost systems in a neighborhood with high shares of 
photovoltaic electricity generation capacity [73], proving that both costs and emissions could be reduced for various solutions, in comparison with scenarios with no battery. Other research works have focused on the combination of heat and power systems, whether by using biomass [74-76] or traditional fuels [77], to meet the energy demands, but also complying with environmental norms and identifying the best compromise solutions. A recent study used multi-objective optimization with genetic algorithms to optimize a novel modification of a combined cooling, heating and power production process through the use of solar collectors, which resulted in a higher efficiency and electricity production than the base system [78]. MOO has also been used to evaluate efficiency trade-offs in heat exchangers within industries that operate with organic Rankine cycles, evaluating thermodynamic variables to obtain results that showed that the heat exchanger design could be optimized, reducing its area by $36 \%$ with an efficiency penalty of only $1 \%$, thus optimizing production costs [79]. On the same note, researchers found the optimal design for a small-scale co-generation system using an ORC, maximizing electrical and cooling power whilst minimizing the overall conductance of the cycle [80]. Most of the works considered using the $\epsilon$-constraint method to find the Pareto optimum for the problem [81-83].

In the energy sector, there are many important challenges owing to the complexity of the problem, from the selection of the best energy source, to the storage and distribution; many factors must be considered and balanced to achieve sustainable energy production. For example, for shale gas exploitation, there are still many questions that must be answered, such as the following: What are the economic and environmental impacts of using this fuel? Can the process be improved to offer a better alternative? In a similar manner, other sources of energy pose their own difficulties and opportunities that can be analyzed from an $\mathrm{MOO}$ perspective.

\section{Application of MOO in Supply Chain Networks}

Globalization has redefined the world of logistics and one of the challenges that arises in this domain is the effective use of supply chains that comply with the needs of suppliers and consumers, while being environmentally friendly. Thus, the very nature of SC is a multi-objective task, since any design or redesign involves trade-offs between various objectives, which are usually at conflict. The end goal of the traditional supply chain is lowering the cost and improving the overall efficiency to maximize the economic benefits. A number of existing studies in the literature has examined the configuration of sustainable global supply chains [84-86] through MOO optimization, evaluating the trade-offs of minimizing costs whilst maximizing their connectivity, applying methods such as the analytic hierarchy process (AHP) to selection processes as a way to complement the procedure. This is also relevant for the optimal planning of oil and gas production (in other words, the hydrocarbon supply chain); after all, these fuels represent an important role in the economy, worldwide. By using optimization tactics to aid in the strategic planning of their supply chains, researchers found they could assist in the trade-off evaluation among different objectives, in some cases maximizing profits and gas flow among supply chain nodes, as well as focusing on the depletion of natural resources [87-89]. Other works focused more on the supply chain's sustainability $[90,91]$; since lowering the carbon footprint has become an important worldwide goal, companies must comply with government regulations. Hence, finding a configuration that includes renewable energy and quantifying its effect on total costs and carbon emissions is attractive [92]. However, this also results in an increase in the overall production costs [93]. To refute this idea, a study focused on closed-loop supply chains (CLSCs), which use technologies to minimize the consumption of resources and energy, reducing carbon footprint to create a socially responsible enterprise. By adopting these technologies into supply chain optimization, they found that it could be possible to increase profits by $11 \%$ and environmental performance by $28 \%$ [94]. Another study also focused on CLSCs, on the system design of photovoltaic systems, addressing their associated costs, environmental impacts and social values, using a real life study in Iran [95], yielding results that demonstrated that, in order to improve environmental and social objectives, 
additional costs are required in comparison with the optimal solution from the economic perspective. Researchers have further developed the sustainability of supply chains by using an MILP model to incorporate economic and environmental data in the SC network, using a motor company as case study, in which the objectives were using high-quality raw materials, lowering pollution emissions and, at the same time, obtaining the highest profitability with the use of sustainability performance indicators [96]. For most supply chains problems, a decision framework is as important as the optimization itself. For example, a study searching for the optimal planning of oil palm value chains by minimizing biodiversity losses and generating value from waste products used, as its main component, a decision framework using a fuzzy analytic hierarchy process (FAHP), in order to plan and evaluate under uncertainty and to incorporate the stakeholders' judgment into the design of the value chain [97].

For this topic, the level of detail of the supply chain remains as the main challenge to design profitable and sustainable networks. From raw materials extraction to end consumer and even final disposal, the involved steps are numerous, thus making it a complex task that goes beyond the transshipment problem and that requires the correct assessment, evaluation and definition of the interactions between all the parts of the SC-sometimes, it can include the design of those parts (processing facilities, for example). As a result of increasing the complexity of the SC, sometimes, mathematical models become large scale non-linear models, whose solutions are a current field of study.

\section{Application of MOO to Process Intensification}

As new and improved technologies emerge and society's priorities change and evolve, chemical engineers are focusing on the redesign of known processes to make them safer, more sustainable and improve their energy efficiency. This is known as process intensification, in which $\mathrm{MOO}$ is a powerful tool to aid in the decision-making process. For instance, a recent study reduced the equipment in the isoamyl acetate process and the production of dioxolane products whilst quantifying economic, sustainability and safety metrics [98]. Another study proposed the use of MOO to find a list of Pareto-optimal solvents to be used in extractive distillation, resulting in an optimized design with a higher process performance [99]. An additional research focused on determining the operating conditions of an industrial phosphoric acid process, minimizing the chemical losses of phosphate and maximizing the productivity of the digestion tank [100]. Other examples of the use of multi-objective optimization in process intensification include works that focus on the optimization of thermodynamics, kinetics and heat/mass transfer [101-107], using strategies for model identification, data processing and design and synthesis of process flowsheets and parameters, which result in frameworks that can be applied in industries to obtain algorithms that present optimal economical and sustainable solutions. A study used genetic algorithms to tune process parameters in order to improve absorption and overall performance in the industrial gas-sweetening process [108]; by evaluating trade-offs, in different scenarios, between the global warming potential and acidification potential as environmental indicators and the net profit as the economic objective, they found that increasing the net profit from USD 60 to 65 million per year increased the GWP by $0.95 \%$. Another research study focused on MOO for the production of commercial gasoline, evaluating the efficiency of the blending process to find the optimal values of specified quality indicators and the volume of commercial product output, maintaining the economic efficiency of the industrial technology [109]. Another study focused on the reduction in energy consumption in the post-combustion $\mathrm{CO}_{2}$ capture process through an evolutionary algorithm, optimizing the capture efficiency and reboiler heat duty with solvent flow rate and concentration as its decision variables [110]. To improve process efficiency in the kraft pulping process, researchers used experimental data to optimize the percentage of lignin in the pulp at the end of the process, in function of the kappa number and the global yield of the process. Since the constraints respected actual operational limits of a real pulp mill, the results obtained could aid the decision-makers in a kraft mill [111]. 
Although process intensification has effectively helped to propose novel configurations for different processes, usually, these are not studied from the controllability perspective. This leads to simplifying the proposed schemes (in the process diagram), when, in reality, the links among the process variables are more complex, sometimes yielding processes that are impossible to control. There also exists the possibility that, by reducing the number of units (for example, in reactive distillation), the process safety and reliability are compromised, due to the merging of steps. These aspects are still the focus of much attention in the current literature.

\section{Application of MOO to Industrial Processes Security Evaluation}

Using safety criteria in the design of any industry is as important as its efficiency or process revenue, since its oblivion could lead to fatal accidents, economic losses and ecological adversities. Processes are assessed to be inherently safer, meaning that they have a low risk level, by reducing or eliminating hazards associated with the materials and operations in the process. Therefore, researchers have approached the use of multiobjective optimization to incorporate inherent safety design into established processes; ideally, these concepts should be taken into account in the design stage [112], resulting in scenarios that aid in the decision-making process in order to find the optimal design. Some authors have used multi-objective optimization combined with quantitative risk analysis tools to re-evaluate plant layouts, evaluating the trade-offs in safety and economic objectives [113-115], while others have used risk assessment to redesign process equipment and networks considering thermodynamic parameters [116-119]. Another approach was made to reduce risk values across all potential hazards in an industry, taking into consideration the constraint of a given safety investment budget, minimizing company costs by reducing the risk of accidents [120]. An algorithm can also be used to select the optimal safety measures [121], considering costs and their contribution to the system risk reduction; the approach yielded results that minimized hazard risks and total cost. Process safety has also been considered in the optimization of supply chains [122] due to the cascading effect that a minor incident could have on a final product, considering the trade-offs between safety and profit, to either maximize profit for specified hazard limits, or to minimize hazard in a supply chain with multiple production plants.

Although the literature on this topic is abundant, there are still open questions specifically aiming to reconcile the economic aspect with the safety of the processes, since they are in conflict with each other; thus, MOO must be used to provide the decision makers with tools that aid in the optimal design and operation of industrial processes. Finally, the simultaneous optimization of the process design considering the safety aspects remains a current trend in the chemical industry and requires further development to properly synthesize inherently safer equipment and processes.

\section{Conclusions}

Multi-objective optimization is a necessary tool for the design, operation, control and optimization of industrial processes. As it can be seen from the literature review, the possible applications are vast and can help improve the performance of the process from different perspectives, or at least give the decision makers the tools to decide what is the best compromise solution between objectives at conflict. The challenges in this area can be divided in two categories. (1) Optimization procedures.: In this context, the scientific community is concerned about how to efficiently solve large-scale nonlinear problems, as well as the application of uncertainty to mathematical models and applications of new techniques for the resolution of conflicts between different objectives, all of these being current trends in the field. (2) Increasing the level of detail of mathematical models: This consists, for instance, in considering individual mass balances or property balances in the water networks design, applying rigorous thermodynamic models in energy systems, simultaneously working on the optimization of environmental and safety indexes along with economic and operational objectives, or including the detailed design of process 
equipment and processing facilities. These aspects can improve the reliability of the final models; however, they represent an additional challenge, namely, the acquisition of data and the inherent complexity of solving these models, which are also open fields in the area.

Author Contributions: Writing original draft preparation, S.C.C.-F. and A.A.R.-P.; Conceptualization, writing, review and editing, supervision, F.N.-R. All authors have read and agreed to the published version of the manuscript.

Funding: This research was funded by CIC UMSNH, grant CIC2021.

Institutional Review Board Statement: Not applicable.

Informed Consent Statement: Not applicable.

Data Availability Statement: Not applicable.

Acknowledgments: The authors acknowledge the financial support of CONACYT and the Cientific Research Council (CIC UMSNH) for the development of this project and the faculty of Chemical Engineering at the Universidad Michoacana de San Nicolás de Hidalgo.

Conflicts of Interest: The authors declare no conflict of interest.

\begin{tabular}{|c|c|}
\hline \multicolumn{2}{|c|}{ Abbreviations } \\
\hline The & ing abbreviations are used in this manu \\
\hline MOO & Multi-objective optimization \\
\hline LP & Linear programming \\
\hline NLP & Non-linear programming \\
\hline MIP & Mixed integer programming \\
\hline MINLP & Mixed integer non-linear programming \\
\hline LCA & Life cycle assessment \\
\hline SWM & Solid waste management \\
\hline CLSC & Closed-loop supply chains \\
\hline FAHP & Fuzzy analytic hierarchy process \\
\hline
\end{tabular}

\section{References}

1. Liu, Q.; Li, X.; Liu, H.; Guo, Z. Multi-objective metaheuristics for discrete optimization problems: A review of the state-of-the-art. Appl. Soft Comput. 2020, 93, 106382. [CrossRef]

2. Marler, R.T.; Arora, J.S. The weighted sum method for multi-objective optimization: New insights. Struct. Multidiscip. Optim. 2010, 41, 853-862. [CrossRef]

3. Jones, D.; Tamiz, M. Practical Goal Programming; Springer: Berlin/Heidelberg, Germany, 2010.

4. Muralikrishna, I.V.; Manickam, V. Life Cycle Assessment. In Environmental Management; Elsevier: Amsterdam, The Netherlands, 2017; pp. 57-75. [CrossRef]

5. Yue, D.; Pandya, S.; You, F. Integrating Hybrid Life Cycle Assessment with Multiobjective Optimization: A Modeling Framework. Environ. Sci. Technol. 2016, 50, 1501-1509. [CrossRef] [PubMed]

6. Zhang, L.; Ji, K.; Liu, W.; Cui, X.; Liu, Y.; Cui, Z. Collaborative Approach for Environmental and Economic Optimization Based on Life Cycle Assessment of End-of-Life Vehicles' Dismantling in China. J. Clean. Prod. 2020, 276, 124288. [CrossRef]

7. Xiong, J.; Zhu, J.; He, Y.; Ren, S.; Huang, W.; Lu, F. The Application of Life Cycle Assessment for the Optimization of Pipe Materials of Building Water Supply and Drainage System. Sustain. Cities Soc. 2020,60, 102267. [CrossRef]

8. Kamalakkannan, S.; Kulatunga, A.K. Optimization of Eco-Design Decisions Using a Parametric Life Cycle Assessment. Sustain. Prod. Consum. 2021, 27, 1297-1316. [CrossRef]

9. Monsiváis-Alonso, R.; Mansouri, S.S.; Román-Martínez, A. Life Cycle Assessment of Intensified Processes towards Circular Economy: Omega-3 Production from Waste Fish Oil. Chem. Eng. Process. Process. Intensif. 2020, 158, 108171. [CrossRef]

10. Pourreza Movahed, Z.; Kabiri, M.; Ranjbar, S.; Joda, F. Multi-Objective Optimization of Life Cycle Assessment of Integrated Waste Management Based on Genetic Algorithms: A Case Study of Tehran. J. Clean. Prod. 2020, 247, 119153. [CrossRef]

11. Ooi, J.K.; Woon, K.S.; Hashim, H. A Multi-Objective Model to Optimize Country-Scale Municipal Solid Waste Management with Economic and Environmental Objectives: A Case Study in Malaysia. J. Clean. Prod. 2021, 316, 128366. [CrossRef]

12. Malmir, T.; Ranjbar, S.; Eicker, U. Improving Municipal Solid Waste Management Strategies of Montréal (Canada) Using Life Cycle Assessment and Optimization of Technology Options. Energies 2020, 13, 5701. [CrossRef]

13. Falahi, M.; Avami, A. Optimization of the Municipal Solid Waste Management System Using a Hybrid Life Cycle AssessmentEnergy Approach in Tehran. J. Mater. Cycles Waste Manag. 2020, 22, 133-149. [CrossRef] 
14. Arnell, M.; Rahmberg, M.; Oliveira, F.; Jeppsson, U. Multi-Objective Performance Assessment of Wastewater Treatment Plants Combining Plant-Wide Process Models and Life Cycle Assessment. J. Water Clim. Chang. 2017, 8, 715-729. [CrossRef]

15. Xie, N.; Liu, Z.; Luo, Z.; Ren, J.; Deng, C.; Yang, S. Multi-Objective Optimization and Life Cycle Assessment of an Integrated System Combining LiBr/H2O Absorption Chiller and Kalina Cycle. Energy Convers. Manag. 2020, 225, 113448. [CrossRef]

16. Wang, J.; Zhou, Y.; Zhang, X.; Ma, Z.; Gao, Y.; Liu, B.; Qin, Y. Robust Multi-Objective Optimization with Life Cycle Assessment of Hybrid Solar Combined Cooling, Heating and Power System. Energy Convers. Manag. 2021, 232, 113868. [CrossRef]

17. Xiao, W.; Cheng, A.; Li, S.; Jiang, X.; Ruan, X.; He, G. A Multi-Objective Optimization Strategy of Steam Power System to Achieve Standard Emission and Optimal Economic by NSGA-II. Energy 2021, 232, 120953. [CrossRef]

18. Yang, P.; Yuan, M.; Liu, Z.; Xie, N.; Liu, Y.; Yang, S. Multi- Objective Optimization and Life Cycle Assessment of a Cascade System Integrating $\mathrm{LiBr} / \mathrm{H}_{2} \mathrm{O}$ Absorption Refrigeration with Transcritical $\mathrm{CO}_{2}$ Power Cycle. Energy Convers. Manag. 2021, $244,114453$. [CrossRef]

19. Dabbaghi, F.; Tanhadoust, A.; Nehdi, M.L.; Nasrollahpour, S.; Dehestani, M.; Yousefpour, H. Life Cycle Assessment MultiObjective Optimization and Deep Belief Network Model for Sustainable Lightweight Aggregate Concrete. J. Clean. Prod. 2021, 318, 128554. [CrossRef]

20. Vaskan, P.; Guillén-Gosálbez, G.; Jiménez, L. Multi-Objective Design of Heat-Exchanger Networks Considering Several Life Cycle Impacts Using a Rigorous MILP-Based Dimensionality Reduction Technique. Appl. Energy 2012, 98, 149-161. [CrossRef]

21. Esquivel-Patiño, G.G.; Nápoles-Rivera, F. Environmental and Energetic Analysis of Coupling a Biogas Combined Cycle Power Plant with Carbon Capture, Organic Rankine Cycles and CO2 Utilization Processes. J. Environ. Manag. 2021, 300, 113746. [CrossRef] [PubMed]

22. Deng, S.; Aydin, R.; Kwong, C.K.; Huang, Y. Integrated Product Line Design and Supplier Selection: A Multi-Objective Optimization Paradigm. Comput. Ind. Eng. 2014, 70, 150-158. [CrossRef]

23. Zhang, H.; Wang, S.; Dai, Y.; Yang, X.; Zhao, J.; Cui, P.; Zhu, Z.; Wang, Y.; Zheng, S.; Gao, J. Multi-Objective Optimization of a Clean, High-Efficiency Synthesis Process of Methyl-Ethyl-Ketone Oxime from Ammoximation. J. Clean. Prod. 2021, $315,128176$. [CrossRef]

24. Sohani, A.; Zamani Pedram, M.; Berenjkar, K.; Sayyaadi, H.; Hoseinzadeh, S.; Kariman, H.; El Haj Assad, M. Techno-EnergyEnviro-Economic Multi-Objective Optimization to Determine the Best Operating Conditions for Preparing Toluene in an Industrial Setup. J. Clean. Prod. 2021, 313, 127887. [CrossRef]

25. Ishaq, H.; Dincer, I. Development and Multi-Objective Optimization of a Newly Proposed Industrial Heat Recovery Based Cascaded Hydrogen and Ammonia Synthesis System. Sci. Total Environ. 2020, 743, 140671. [CrossRef]

26. Flegiel, F.; Sharma, S.; Rangaiah, G.P. Development and Multiobjective Optimization of Improved Cumene Production Processes. Mater. Manuf. Process. 2015, 30, 444-457. [CrossRef]

27. Goli, A.; Zare, H.K. Hybrid Artificial Intelligence and Robust Optimization for a Multi-Objective Product Portfolio Problem Case Study: The Dairy Products Industry. Comput. Ind. Eng. 2019, 137, 106090. [CrossRef]

28. Feng, Q.; Liu, L.; Zhou, X. Automated Multi-Objective Optimization for Thin-Walled Plastic Products Using Taguchi, ANOVA, and Hybrid ANN-MOGA. Int. J. Adv. Manuf. Technol. 2020, 106, 559-575. [CrossRef]

29. Meramo-Hurtado, S.-I.; González-Delgado, A.-D. Biorefinery Synthesis and Design Using Sustainability Parameters and Hierarchical/3D Multi-Objective Optimization. J. Clean. Prod. 2019, 240, 118134. [CrossRef]

30. Jugwanth, Y.; Sewsynker-Sukai, Y.; Gueguim Kana, E.B. Valorization of Sugarcane Bagasse for Bioethanol Production through Simultaneous Saccharification and Fermentation: Optimization and Kinetic Studies. Fuel 2020, 262, 116552. [CrossRef]

31. Sánchez Bautista, A.F.; Santibañez-Aguilar, J.E.; You, F.; Ponce-Ortega, J.M. Optimal Planning of Distributed Systems of Refineries and Biorefineries Considering Pollution Trading with Forest Plantations. In Computer Aided Chemical Engineering; Elsevier: Amsterdam, The Netherlands, 2016; Volume 38, pp. 1099-1104. [CrossRef]

32. Murillo-Alvarado, P.E.; Ponce-Ortega, J.M.; Serna-González, M.; Castro-Montoya, A.J.; El-Halwagi, M.M. Optimization of Pathways for Biorefineries Involving the Selection of Feedstocks, Products, and Processing Steps. Ind. Eng. Chem. Res. 2013, 52, 5177-5190. [CrossRef]

33. Alizadeh Afrouzy, Z.; Nasseri, S.H.; Mahdavi, I.; Paydar, M.M. A Fuzzy Stochastic Multi-Objective Optimization Model to Configure a Supply Chain Considering New Product Development. Appl. Math. Model. 2016, 40, 7545-7570. [CrossRef]

34. Ji, X.; Gao, Q.; Wang, H. A Bilevel-Optimization Approach to Determine Product Specifications during the Early Phases of Product Development: Increase Customer Value and Reduce Design Risks. Expert Syst. Appl. 2022, 188, 116012. [CrossRef]

35. San Juan, J.L.; Caligan, C.J.; Garcia, M.M.; Mitra, J.; Mayol, A.P.; Culaba, A. Multi-Objective Optimization of an Integrated Algal and Sludge-Based Bioenergy Park and Wastewater Treatment System. Sustainability 2020, 12, 7793. [CrossRef]

36. Rerat, C.; Papadokonstantakis, S.; Hungerbühler, K. Integrated Waste Management in Batch Chemical Industry Based on Multi-Objective Optimization. J. Air Waste Manag. Assoc. 2013, 63, 349-366. [CrossRef] [PubMed]

37. Padrón-Páez, J.I.; Almaraz, S.D.-L.; Román-Martínez, A. Sustainable Wastewater Treatment Plants Design through Multiobjective Optimization. Comput. Chem. Eng. 2020, 140, 106850. [CrossRef]

38. Gormaz-Cuevas, D.; Riffo-Rivas, J.; Montastruc, L.; Brüning-González, M.; Díaz-Alvarado, F. A Multi-Objective Optimization Model to Plan City-Scale Water Systems with Economic and Environmental Objectives: A Case Study in Santiago, Chile. J. Clean. Prod. 2021, 279, 123737. [CrossRef] 
39. Qiao, J.; Zhang, W. Dynamic Multi-Objective Optimization Control for Wastewater Treatment Process. Neural Comput. Applic 2018, 29, 1261-1271. [CrossRef]

40. Caligan, C.J.A.; Garcia, M.M.S.; Mitra, J.L.; Mayol, A.P.; San Juan, J.L.G.; Culaba, A.B. Multi-Objective Optimization of Water Exchanges between a Wastewater Treatment Facility and Algal Biofuel Production Plant. IOP Conf. Ser. Earth Environ. Sci. 2020, 463, 012050. [CrossRef]

41. Moazeni, F.; Khazaei, J. Interactive Nonlinear Multiobjective Optimal Design of Water Distribution Systems Using Pareto Navigator Technique. Sustain. Cities Soc. 2021, 73, 103110. [CrossRef]

42. Zhang, K.; Yan, H.; Zeng, H.; Xin, K.; Tao, T. A Practical Multi-Objective Optimization Sectorization Method for Water Distribution Network. Sci. Total. Environ. 2019, 656, 1401-1412. [CrossRef]

43. Lence, B.J.; Moosavian, N.; Daliri, H. Fuzzy Programming Approach for Multiobjective Optimization of Water Distribution Systems. J. Water Resour. Plan. Manag. 2017, 143, 04017020. [CrossRef]

44. Xu, Z.; Yao, L.; Chen, X. Urban Water Supply System Optimization and Planning: Bi-Objective Optimization and System Dynamics Methods. Comput. Ind. Eng. 2020, 142, 106373. [CrossRef]

45. Sankary, N.; Ostfeld, A. Multiobjective Optimization of Inline Mobile and Fixed Wireless Sensor Networks under Conditions of Demand Uncertainty. J. Water Resour. Plan. Manag. 2018, 144, 04018043. [CrossRef]

46. Ong, M.C.; Leong, Y.T.; Wan, Y.K.; Chew, I.M.L. Multi-Objective Optimization of Integrated Water System by FUCOM-VIKOR Approach. Process. Integr. Optim. Sustain. 2021, 5, 43-62. [CrossRef]

47. Solgi, M.; Bozorg-Haddad, O.; Loáiciga, H.A. A multi-objective optimization model for operation of intermittent water distribution networks. Water Supply 2020, 20, 2630-2647. [CrossRef]

48. Elshaboury, N.; Attia, T.; Marzouk, M. Application of evolutionary optimization algorithms for rehabilitation of water distribution networks. J. Constr. Eng. Manag. 2020, 146, 04020069. [CrossRef]

49. Aalami, M.T.; Nourani, V.; Fazaeli, H. Developing a surface water resources allocation model under risk conditions with a multi-objective optimization approach. Water Supply 2020, 20, 1167-1177. [CrossRef]

50. Naghdi, S.; Bozorg-Haddad, O.; Khorsandi, M.; Chu, X. Multi-objective optimization for allocation of surface water and groundwater resources. Sci. Total. Environ. 2021, 776, 146026. [CrossRef]

51. Sadr, S.M.; Johns, M.B.; Memon, F.A.; Duncan, A.P.; Gordon, J.; Gibson, R.; Butler, D. Development and application of a multiobjective-optimization and multi-criteria-based decision support tool for selecting optimal water treatment technologies in india. Water 2020, 12, 2836. [CrossRef]

52. De-León Almaraz, S.; Boix, M.; Montastruc, L.; Azzaro-Pantel, C.; Liao, Z.; Domenech, S. Design of a Water Allocation and Energy Network for Multi-Contaminant Problems Using Multi-Objective Optimization. Process. Saf. Environ. Prot. 2016, 103, 348-364. [CrossRef]

53. Sharma, S.; Rangaiah, G.P. Multi-Objective Optimization of Heat Integrated Water Networks in Petroleum Refineries. In Computer Aided Chemical Engineering; Elsevier: Amsterdam, The Netherlands, 2014; Volume 33, pp. 1531-1536. [CrossRef]

54. Chijin, Z.; Congjing, R.; Zuwei, L.; Jingyuan, S.; Jingdai, W.; Yongrong, Y. Recent Progresses on Optimal Design of Heat Integrated Water Allocation Network. China Pet. Process. Petrochem. Technol. 2021, $23,69$.

55. Liu, L.; Sheng, Y.; Zhuang, Y.; Zhang, L.; Du, J. Multiobjective Optimization of Interplant Heat Exchanger Networks Considering Utility Steam Supply and Various Locations of Interplant Steam Generation/Utilization. Ind. Eng. Chem. Res. 2020, 59, 14433-14446. [CrossRef]

56. de Dios, L.G.; Boix, M.; Sauvage, S.; Touche, I.; Cakir, R.; Montastruc, L.; Perez, J.M.S. Multiobjective Optimization of EcoIndustrial Parks: Evaluation of Environmental Impacts at the Watershed Scale. In Computer Aided Chemical Engineering; Elsevier: Amsterdam, The Netherlands, 2018; Volume 43, pp. 67-72. [CrossRef]

57. Ramos, M.A.; Rocafull, M.; Boix, M.; Aussel, D.; Montastruc, L.; Domenech, S. Utility Network Optimization in Eco-Industrial Parks by a Multi-Leader Follower Game Methodology. Comput. Chem. Eng. 2018, 112, 132-153. [CrossRef]

58. Afshari, H.; Farel, R.; Peng, Q. Challenges of Value Creation in Eco-Industrial Parks (EIPs): A Stakeholder Perspective for Optimizing Energy Exchanges. Resour. Conserv. Recycl. 2018, 139, 315-325. [CrossRef]

59. Tiu, B.T.C.; Cruz, D.E. An MILP Model for Optimizing Water Exchanges in Eco-Industrial Parks Considering Water Quality. Resour. Conserv. Recycl. 2017, 119, 89-96. [CrossRef]

60. Leong, Y.T.; Lee, J.-Y.; Tan, R.R.; Foo, J.J.; Chew, I.M.L. Multi-Objective Optimization for Resource Network Synthesis in Eco-Industrial Parks Using an Integrated Analytic Hierarchy Process. J. Clean. Prod. 2017, 143, 1268-1283. [CrossRef]

61. Ahmed, R.O.; Al-Mohannadi, D.M.; Linke, P. Multi-Objective Resource Integration for Sustainable Industrial Clusters. J. Clean. Prod. 2021, 316, 128237. [CrossRef]

62. Wang, C.; Olsson, G.; Liu, Y. Coal-Fired Power Industry Water-Energyemission Nexus: A Multi-Objective Optimization. J. Clean. Prod. 2018, 203, 367-375. [CrossRef]

63. Ghiasi, M. Detailed Study, Multi-Objective Optimization, and Design of an AC-DC Smart Microgrid with Hybrid Renewable Energy Resources. Energy 2019, 169, 496-507. [CrossRef]

64. Lee, J.-Y.; Aviso, K.B.; Tan, R.R. Multi-Objective Optimisation of Hybrid Power Systems under Uncertainties. Energy 2019, 175, 1271-1282. [CrossRef]

65. Majewski, D.E.; Wirtz, M.; Bardow, A. Robust Multi-Objective Optimization for Sustainable Design of Distributed Energy Supply Systems. Comput. Chem. Eng. 2017, 102, 26-39. [CrossRef] 
66. Jing, R.; Zhu, X.; Wang, W.; Meng, C.; Shah, N.; Zhao, Y. A Multi-Objective Optimization and Multi-Criteria Evaluation Integrated Framework for Distributed Energy System Optimal Planning. Energy Convers. Manag. 2018, 166, 445-462. [CrossRef]

67. Jiang, M.; An, H.; Gao, X.; Liu, D.; Jia, N.; Xi, X. Consumption-Based Multi-Objective Optimization Model for Minimizing Energy Consumption: A Case Study of China. Energy 2020, 208, 118384. [CrossRef]

68. Bagaber, S.A.; Yusoff, A.R. Energy and Cost Integration for Multi-Objective Optimisation in a Sustainable Turning Process. Measurement 2019, 136, 795-810. [CrossRef]

69. Breen, M.; Upton, J.; Murphy, M.D. Photovoltaic systems on dairy farms: Financial and renewable multi-objective optimization (FARMOO) analysis. Appl. Energy 2020, 278, 115534. [CrossRef]

70. Li, L.; Liu, P.; Li, Z.; Wang, X. A Multi-Objective Optimization Approach for Selection of Energy Storage Systems. Comput. Chem. Eng. 2018, 115, 213-225. [CrossRef]

71. Wang, X.; Yang, C.; Huang, M.; Ma, X. Multi-Objective Optimization of a Gas Turbine-Based CCHP Combined with Solar and Compressed Air Energy Storage System. Energy Convers. Manag. 2018, 164, 93-101. [CrossRef]

72. Chen, S.; Arabkoohsar, A.; Yang, Y.; Zhu, T.; Nielsen, M.P. Multi-objective optimization of a combined cooling, heating, and power system with subcooled compressed air energy storage considering off-design characteristics. Appl. Therm. Eng. 2021, 187, 116562. [CrossRef]

73. Schram, W.L.; AlSkaif, T.; Lampropoulos, I.; Henein, S.; Van Sark, W.G. On the trade-off between environmental and economic objectives in community energy storage operational optimization. IEEE Trans. Sustain. Energy 2020, 11, 2653-2661. [CrossRef]

74. Asni, T.; Andiappan, V. Optimal Design of Biomass Combined Heat and Power System Using Fuzzy Multi-Objective Optimisation: Considering System Flexibility, Reliability, and Cost. Process. Integr. Optim. Sustain. 2021, 5, 207-229. [CrossRef]

75. Li, X.; Gui, D.; Zhao, Z.; Li, X.; Wu, X.; Hua, Y.; Guo, P.; Zhong, H. Operation Optimization of Electrical-Heating Integrated Energy System Based on Concentrating Solar Power Plant Hybridized with Combined Heat and Power Plant. J. Clean. Prod. 2021, 289, 125712. [CrossRef]

76. Li, Y.; Wang, J.; Zhao, D.; Li, G.; Chen, C. A Two-Stage Approach for Combined Heat and Power Economic Emission Dispatch: Combining Multi-Objective Optimization with Integrated Decision Making. Energy 2018, 162, 237-254. [CrossRef]

77. Santibanez-Borda, E.; Korre, A.; Nie, Z.; Durucan, S. A Multi-Objective Optimisation Model to Reduce Greenhouse Gas Emissions and Costs in Offshore Natural Gas Upstream Chains. J. Clean. Prod. 2021, 297, 126625. [CrossRef]

78. Cao, Y.; Mohamed, A.M.; Dahari, M.; Delpisheh, M.; Haghghi, M.A. Performance enhancement and multi-objective optimization of a solar-driven setup with storage process using an innovative modification. J. Energy Storage 2020, 32, 101956. [CrossRef]

79. Bufi, E.A.; Camporeale, S.; Fornarelli, F.; Fortunato, B.; Pantaleo, A.M.; Sorrentino, A.; Torresi, M. Parametric Multi-Objective Optimization of an Organic Rankine Cycle with Thermal Energy Storage for Distributed Generation. Energy Procedia 2017, 126, 429-436. [CrossRef]

80. Rodriguez Sotomonte, C.A.; Correa Veloso, T.G.; Coronado, C.J.R.; Rosa do Nascimento, M.A. Multi-Objective Optimization for a Small Biomass Cooling and Power Cogeneration System Using Binary Mixtures. Appl. Therm. Eng. 2021, 182, 116045. [CrossRef]

81. Hernández-Romero, I.M.; Nápoles-Rivera, F.; Flores-Tlacuahuac, A. Optimal Design of the Ocean Thermal Energy Conversion Systems Involving Weather and Energy Demand Variations. Chem. Eng. Process. Process. Intensif. 2020, 157, 108-114. [CrossRef]

82. Martín, M.; Martínez, A. A Methodology for Simultaneous Process and Product Design in the Formulated Consumer Products Industry: The Case Study of the Detergent Business. Chem. Eng. Res. Des. 2013, 91, 795-809. [CrossRef]

83. Martín, M.; Grossmann, I.E. Energy Optimization of Bioethanol Production via Gasification of Switchgrass. AIChE J. 2011, 57, 3408-3428. [CrossRef]

84. Mokhtari, H.; Fattahi, M. A Multi-Objective Optimization Approach for Green and Resilient Supply Chain Network Design: A Real-Life Case Study. J. Clean. Prod. 2021, 278, 123199. [CrossRef]

85. Margolis, J.T.; Sullivan, K.M.; Mason, S.J.; Magagnotti, M. A Multi-Objective Optimization Model for Designing Resilient Supply Chain Networks. Int. J. Prod. Econ. 2018, 204, 174-185. [CrossRef]

86. Resat, H.G.; Unsal, B. A Novel Multi-Objective Optimization Approach for Sustainable Supply Chain: A Case Study in Packaging Industry. Sustain. Prod. Consum. 2019, 20, 29-39. [CrossRef]

87. Attia, A.M.; Ghaithan, A.M.; Duffuaa, S.O. A Multi-Objective Optimization Model for Tactical Planning of Upstream Oil \& Gas Supply Chains. Comput. Chem. Eng. 2019, 128, 216-227. [CrossRef]

88. Asala, H.I.; Chebeir, J.A.; Manee, V.; Gupta, I.; Dahi-Taleghani, A.; Romagnoli, J.A. An Integrated Machine-Learning Approach to Shale-Gas Supply-Chain Optimization and Refrac Candidate Identification. SPE Reserv. Eval. Eng. 2019, 22, 1201-1224. [CrossRef]

89. Zarei, J.; Amin-Naseri, M.R. An Integrated Optimization Model for Natural Gas Supply Chain. Energy 2019, 185, 1114-1130. [CrossRef]

90. Jian, J.; Guo, Y.; Jiang, L.; An, Y.; Su, J. A Multi-Objective Optimization Model for Green Supply Chain Considering Environmental Benefits. Sustainability 2019, 11, 5911. [CrossRef]

91. Canales-Bustos, L.; Santibañez-González, E.; Candia-Véjar, A. A Multi-Objective Optimization Model for the Design of an Effective Decarbonized Supply Chain in Mining. Int. J. Prod. Econ. 2017, 193, 449-464. [CrossRef]

92. Sarkar, B.; Omair, M.; Choi, S.-B. A Multi-Objective Optimization of Energy, Economic, and Carbon Emission in a Production Model under Sustainable Supply Chain Management. Appl. Sci. 2018, 8, 1744. [CrossRef]

93. Pishvaee, M.S.; Torabi, S.A.; Razmi, J. Credibility-Based Fuzzy Mathematical Programming Model for Green Logistics Design under Uncertainty. Comput. Ind. Eng. 2012, 62, 624-632. [CrossRef] 
94. Banasik, A.; Kanellopoulos, A.; Claassen, G.D.H.; Bloemhof-Ruwaard, J.M.; van der Vorst, J.G.A.J. Closing Loops in Agricultural Supply Chains Using Multi-Objective Optimization: A Case Study of an Industrial Mushroom Supply Chain. Int. J. Prod. Econ. 2017, 183, 409-420. [CrossRef]

95. Nili, M.; Seyedhosseini, S.M.; Jabalameli, M.S.; Dehghani, E. A Multi-Objective Optimization Model to Sustainable Closed-Loop Solar Photovoltaic Supply Chain Network Design: A Case Study in Iran. Renew. Sustain. Energy Rev. 2021, 150, 111428. [CrossRef]

96. Ehtesham Rasi, R.; Sohanian, M. A Multi-Objective Optimization Model for Sustainable Supply Chain Network with Using Genetic Algorithm. JM2 2021, 16, 714-727. [CrossRef]

97. Tapia, J.F.D.; Samsatli, S. Integrating Fuzzy Analytic Hierarchy Process into a Multi-Objective Optimisation Model for Planning Sustainable Oil Palm Value Chains. Food Bioprod. Process. 2020, 119, 48-74. [CrossRef]

98. Castillo-Landero, A.; Ortiz-Espinoza, A.P.; Jiménez-Gutiérrez, A. A Process Intensification Methodology Including Economic, Sustainability, and Safety Considerations. Ind. Eng. Chem. Res. 2019, 58, 6080-6092. [CrossRef]

99. Zhou, T.; Song, Z.; Zhang, X.; Gani, R.; Sundmacher, K. Optimal Solvent Design for Extractive Distillation Processes: A Multiobjective Optimization-Based Hierarchical Framework. Ind. Eng. Chem. Res. 2019, 58, 5777-5786. [CrossRef]

100. Bouchkira, I.; Latifi, A.M.; Khamar, L.; Benjelloun, S. Modeling and multi-objective optimization of the digestion tank of an industrial process for manufacturing phosphoric acid by wet process. Comput. Chem. Eng. 2022, 156, 107536. [CrossRef]

101. Lu, J.; Wang, Q.; Zhang, Z.; Tang, J.; Cui, M.; Chen, X.; Liu, Q.; Fei, Z.; Qiao, X. Surrogate Modeling-Based Multi-Objective Optimization for the Integrated Distillation Processes. Chem. Eng. Process. Process. Intensif. 2021, 159, 108224. [CrossRef]

102. Alcocer-García, H.; Segovia-Hernández, J.G.; Prado-Rubio, O.A.; Sánchez-Ramírez, E.; Quiroz-Ramírez, J.J. Multi-Objective Optimization of Intensified Processes for the Purification of Levulinic Acid Involving Economic and Environmental Objectives. Chem. Eng. Process. Process. Intensif. 2019, 136, 123-137. [CrossRef]

103. Chen, X.; Shao, Z.; Gu, X.; Feng, L.; Biegler, L.T. Process Intensification of Polymerization Processes with Embedded Molecular Weight Distributions Models: An Advanced Optimization Approach. Ind. Eng. Chem. Res. 2019, 58, 6133-6145. [CrossRef]

104. Hasanpour, A.; Farhadi, M.; Sedighi, K. Intensification of Heat Exchangers Performance by Modified and Optimized Twisted Tapes. Chem. Eng. Process. Process. Intensif. 2017, 120, 276-285. [CrossRef]

105. Guzmán Martínez, C.; Nápoles Rivera, F.; Castro-Montoya, A. Multi-Objective Optimization of Bioethanol Reactive Dehydration Processes Using Genetic Algorithms. Sep. Sci. Technol. 2021, 63, 1-16. [CrossRef]

106. Shahhosseini, H.R.; Iranshahi, D.; Saeidi, S.; Pourazadi, E.; Klemeš, J.J. Multi-Objective Optimisation of Steam Methane Reforming Considering Stoichiometric Ratio Indicator for Methanol Production. J. Clean. Prod. 2018, 180, 655-665. [CrossRef]

107. Fonseca, J.D.; Latifi, A.M.; Orjuela, A.; Rodríguez, G.; Gil, I.D. Modeling, Analysis and Multi-Objective Optimization of an Industrial Batch Process for the Production of Tributyl Citrate. Comput. Chem. Eng. 2020, 132, 106603. [CrossRef]

108. Tikadar, D.; Gujarathi, A.M.; Guria, C. Multi-Objective Optimization of Industrial Gas-Sweetening Operations Using Economic and Environmental Criteria. Process. Saf. Environ. Prot. 2020, 140, 283-298. [CrossRef]

109. Ivanchina, E.D.; Ivashkina, E.N.; Chuzlov, V.A.; Belinskaya, N.S.; Dementyev, A. Y. Formation of the Component Composition of Blended Hydrocarbon Fuels as the Problem of the Multi-Objective Optimization. Chem. Eng. J. 2020, 383, 121283. [CrossRef]

110. Hosseini-Ardali, S.M.; Hazrati-Kalbibaki, M.; Fattahi, M.; Lezsovits, F. Multi-Objective Optimization of Post Combustion CO 2 Capture Using Methyldiethanolamine (MDEA) and Piperazine (PZ) Bi-Solvent. Energy 2020, 211, 119035. [CrossRef]

111. Larraín, S.; Pradenas, L.; Pulkkinen, I.; Santander, F. Multiobjective Optimization of a Continuous Kraft Pulp Digester Using SPEA2. Comput. Chem. Eng. 2020, 143, 107086. [CrossRef]

112. Ramírez-Márquez, C.; Contreras-Zarazúa, G.; Martín, M.; Segovia-Hernández, J.G. Safety, Economic, and Environmental Optimization Applied to Three Processes for the Production of Solar-Grade Silicon. ACS Sustain. Chem. Eng. 2019, 7, 5355-5366. [CrossRef]

113. Medina-Herrera, N.; Jiménez-Gutiérrez, A.; Grossmann, I.E. A Mathematical Programming Model for Optimal Layout Considering Quantitative Risk Analysis. Comput. Chem. Eng. 2014, 68, 165-181. [CrossRef]

114. Wang, R.; Wang, Y.; Gundersen, T.; Wu, Y.; Feng, X.; Liu, M. A Multi-Objective Optimization Method for Industrial Park Layout Design: The Trade-off between Economy and Safety. Chem. Eng. Sci. 2021, 235, 116471. [CrossRef]

115. Martinez-Gomez, J.; Nápoles-Rivera, F.; Ponce-Ortega, J.M.; Serna-González, M.; El-Halwagi, M.M. Siting Optimization of Facility and Unit Relocation with the Simultaneous Consideration of Economic and Safety Issues. Ind. Eng. Chem. Res. 2014, 53, 3950-3958. [CrossRef]

116. Nemet, A.; Klemes, J.J.; Kravanja, Z. Heat Exchanger Network Synthesis Considering Risk Assessment for Entire Network Lifetime. Chem. Eng. Trans. 2017, 57, 307-312. [CrossRef]

117. Al Ani, Z.; Thafseer, M. Towards Process, Energy and Safety Based Criteria for Multi-Objective Optimization of Industrial Acid Gas Removal Process. Process. Saf. Environ. Prot. 2020, 140, 86-99. [CrossRef]

118. Lee, Y.; Kim, J.; Ahmed, U.; Kim, C.; Lee, Y.-W. Multi-Objective Optimization of Organic Rankine Cycle (ORC) Design Considering Exergy Efficiency and Inherent Safety for LNG Cold Energy Utilization. J. Loss Prev. Process. Ind. 2019, 58, 90-101. [CrossRef]

119. Martinez-Gomez, J.; Nápoles-Rivera, F.; Ponce-Ortega, J.M.; El-Halwagi, M.M. Optimization of the Production of Syngas from Shale Gas with Economic and Safety Considerations. Appl. Therm. Eng. 2017, 110, 678-685. [CrossRef]

120. Roy, S.; Gupta, A. Safety Investment Optimization in Process Industry: A Risk-Based Approach. J. Loss Prev. Process. Ind. 2020, 63, 104022. [CrossRef] 
121. Eslami Baladeh, A.; Cheraghi, M.; Khakzad, N. A Multi-Objective Model to Optimal Selection of Safety Measures in Oil and Gas Facilities. Process. Saf. Environ. Prot. 2019, 125, 71-82. [CrossRef]

122. Roy, N.; Mannan, M.S.; Hasan, M.F. Systematic Incorporation of Inherent Safety in Hazardous Chemicals Supply Chain Optimization. J. Loss Prev. Process. Ind. 2020, 68, 104262. [CrossRef] 